\title{
Study of Deformation Processes after Hard Turning through Acoustic Emission
}

Doc. Ing. Mária Čilliková, PhD., prof. Dr. Ing. Miroslav Neslušan, prof. Ing. Anna Mičietová, PhD., Ing. Jozef Mrázik Department of Machining and Manufacturing Engineering, Faculty of Mechanical Engineering, University of Žilina, Univerzitná 1, 010 26, Slovak Republic, maria.cillikova@fstroj.uniza.sk

\begin{abstract}
The paper deals with analysis of deformation processes and related aspects of the chip formation as the chip thickness, the chip ratio and the shear angle during turning hardened steel 100Cr6. This paper investigates influence of feed on the mentioned aspects through the metallographic analysis, calculation of the significant aspects of deformation processes and the following experimental study. This experimental study is based on application acoustic emission sensors. The results in this study reports that feed significantly does not affect such parameters as the chip ratio, deformation angle in the cutting zone. On the other hand, experimental study indicates that increasing of feed in hard turning causes increasing of the process instability and increasing intensity of deformation processes in the cutting zone.
\end{abstract}

Keywords: turning, hardened steel, chip segmentation, acoustic emission

\section{Acknowledgment}

This project is solved under the financial support of KEGA agency (project n. 031ŽU-04/2011).

\section{References}

[1] TONSHOFF, H.K. - ARENDT, C - BEN MOR, R. (2000). Cutting of Hardened Steel, CIRP Annals 49/2/2000, p. $547-564$

[2] SHAW, M.C. (1998). The Mechanism of Chip Formation with Hard Turning Steel, CIRP Annals 47/1/1998, p. $77-82$

[3] RECHT, R.F. (1964). Catastrophic Thermoplastic Shear, Trans ASME, 86 (1964), p. 189-193

[4] NAKAYAMA, K. - ARAI, M. - KANDA, T. (1988). Machining Characteristics of Hardened Steels, CIRP Annals 37/1/1988, p.89-92

[5] KOMANDURI, R. - BROWN, R.H. (1981) On the Mechanics of Chip Segmentation in machining, J. of Eng. For Ind. Trans. ASME, 1981, 103:33-51

[6] KONING, W. - BERKTOLD, A. - KOCH, K.F. (1993). Turning versus Grinding-A comparison of Surface Integrity Aspects and Attainable Accuracies, CIRP Annals, 1993, 42/1, p.39- 43

[7] POUlACHON, G. - MOISAN, A. (1998). Contribution to the Study of the Cutting Mechanism during High Speed Machining of Hardened Steel, CIRP Annals, 47/1/1998, p.73-76

[8] ElBestaWI, M. A. - SRIVASTAVA, A. K. - El-WARDANY, T. I. (1996) A Model For Chip Formation During Machining of Hardened Steel, CIRP Annals 45/1/1996, p. 71-76

[9] SHAW, M. C. - Vyas, A. (1998). The Mechanism of Chip Formation with Hard Turning Steel, CIRP Annals 47/1/1998, p. 77-82

[10] DORNFELD, D. A. (1984). Acoustic emission in monitoring and analysis in manufacturing, Proceedings of AE Monitoring. Anal. Manuf. 14 (1984) Page 124

[11] INASAKI, I. (1998). Application of acoustic emission sensor for monitoring machining processes, Ultrasonics 36 (1998), p. 273-281

[12] KUNDRÁK, J. (2011). Alternative machining procedures of hardened steels, in: Manufacturing Technology, XI/2011, ISSN 1213-2489, p. $32-39$.

[13] JERSÁK, J., et. all. (2010). Surface integrity of hardened bearing steel after milling, in: Manufacturing Technology, X/2010, ISSN 1213-2489, p. $80-87$.

[14] KOCMAN, K. (2002). Environmental aspects of High Speed Cutting, in: Manufacturing Technology, III/2002, ISSN 1213-2489, p. 7 - 12. 